\title{
RANCANG BANGUN ALAT PENGAMAN BRANKAS MENGGUNAKAN SENSOR SIDIK JARI BERBASIS ARDUINO
}

\author{
Okta Rea Arsyad, Kurnia, P. Kartika \\ Program Studi Sistem Komputer S1, Fakultas Teknik Informatika \\ Universitas Islam Balitar, Jalan Majapahit Blitar, Indonesia \\ oktarea21@gmail.com
}

\begin{abstract}
ABSTRAK
Sistem ini dirancang otomatis untuk keamanan dalam pintu brankas dengan menggunakan alat pengamanan berupa sensor sidik jari berbasis arduino. Alat ini dapat digunakan sebagai sistem kontrol keamanan pada pintu brankas, pengguna tidak perlu menggunakan keamanan manual seperti halnya kunci dan alat ini juga dilengkapi dengan alarm sebagai penanda ketika sensor sidik jari diakses oleh orang lain yang bukan pemiliknya maka alarm ini akan berbunyi. Sistem ini terdiri dari perangkat keras dan perangkat lunak. Perangkat kerasnya terdiri dari satu Arduino Uno,Sensor sidik jari,buzzer,selenoid door,lcd lalu perangakat lunak pada sistem ini menggunakan program arduino IDE. Sitem ini berjalan jika sensor sidik jari mendeteksi jari dari pengguna atau pemilik brankas maka selenoid sebagai pengunci pintu akan terbuka, sebaliknya jika sensor tidak mendeteksi jari dari pengguna atau pemilik maka selenoid sebagai pengunci pintu tidak akan terbuka dan alarm akan berbunyi. Alat pengaman pada brankas ini secara efektif dapat digunakan sebagai keamanan pada brankas yang merupakan media penyimpanan barang-barang yang berharga (sertiikat,uang,emas,dll).
\end{abstract}

Kata kunci : brankas,kontrol keamanan pintu brankas,arduino uno

\section{PENDAHULUAN}

\subsection{Latar Belakang}

Pada zaman saat ini merupakan zaman dimana kemajuan teknologi sangat difungsikan, karena sangat membantu tugas manusia dalam melakukan kegiatan sehari - hari baik itu pekerjaan ataupun aktivitas lainya. Teknologi yang banyak digunakan pada saat adalah mikrokontroler, mikrokontroler merupakan teknologi yang sebelumnya manual menjadi otomatis sehingga dapat diterapkan pada alat alat elektronik saat ini. Seiring majunya teknologi diikuti pula dengan tingkat kecerdasan pada manusia, sehingga manusia selalu ingin menciptakan inovasi - inovasi yang berkemajuan, namun disamping itu dapat menimbulkan pula kejahatan dimasyarakat. Kejahatan - kejahatan yang terjadi saat ini banyak membuat orang resah, dikarenakan kejahatan yang dilakukan merupakan kejahatan yang terjadi didalam ruangan tertentu, seperti halnya perampokan pada bank, perampokan pada toko, perampokan pada rumah, dan mereka pastinya mencari harta simpanan korban yang biasanya disimpan pada brankas. Namun keamanan yang adasaatini kurang memadai salah satunya pengamanan pada brankas.

Seperti yang ketahui bahwa brankas merupakan tempat untuk menyimpan uang serta barang-barang berharga dan penting lainya. Dikarenakan pengamanan pada brankas saat ini masih minim dan masih menggunakan pengamanan cara yang lama sehingga memudahkan para pelaku kejahatan untuk membobolnya ataupun merusaknya, Jadi untuk mencegah dari adanya tindak kejahatan seperti itu maka diperlukan pengaman yang memadai serta alat yang canggih dan modern dalam mengikuti perkembangan teknologi saat ini, Sehingga sistem keamanan pun lebih terjamin.

\subsection{Rumusan Masalah}

Dari latar belakang tersebut maka dicari suatu pemecah masalah yaitu :

1. Bagaimana rancang bangun brankas otomatis dengan sensor sidik jari?

2. Bagaimana meningkatkankeamananbrankasdengan adanya buzzer dan selenoid door?

3. Bagaimana unjuk kerja alatpengamanbrankasmenggunakan sensor sidik jari berbasis arduino?

\section{TINJAUAN PUSTAKA}

\subsection{Penelitian Terdahulu}

Penelitian yang dilakukan oleh Eni Yuliza, Toibah Umi Kalsum (2015) yang berjudul Alat keamanan pintu brankas berbasis sensor sidik jari Dan password digital dengan menggunakan Mikrokontroler artmega 16. Penelitian tersebut berkaitan dengan penggunaan sensor sidik jari dan Password digital beserta arduino artmega 16 sebagai mikrokontrolernya ,ini merupakan sebuah alat pengaman pintu yang terdapat pada brankas untuk mengamankan dari tindak kejahatan pencurian, perampokan, dll. Hasil dari penelitian tersebut adalah sebagai berikut. Pertama brankas ini menggunakan sensor sidik jari sebagai akses utama masuk atau terbukanya terhadap pintu brankas. Kedua password digital digunakan ketika sensor sidik jari tidak terdeteksi. Atmega16 sebagai mikrokontroler yang mengatur berjalanya sensor sidik jari dan password 
digital sebagaimana fungsinya, artmega16 akan mulai memproses input ketika akses pada jari pengguna ke sensor sidik jari dan password digital saat sensor sidik jari gagal, saat input dari sidik jari pengguna bisa dibaca oleh sensor sidik jari makan otomatis pintu akan terbuka.

\subsection{Brankas}

Brankas merupakan lemari berbentuk kotak dan berbahan dasar besi yang tahan api tempat penyimpanan barang-barang berharga (seperti uang, surat-surat berharga, perhiasan, dll) biasanya difungsikan untuk melindungi barang-barang berharga dari adanya bahaya kebakaran dan pencurian/pembongkaran paksa, yang terbuat dari bahan dasar besi dan baja yang sistem pengunciannya menggunakan kunci kombinasi atau digital lock.

Brankas umumnya berbentuk kotak. Ada berbagai macam jenis brankas, dari ukuran kecil dan portabel, serta brankas yang biasanya terpasang di dinding, mau pun brankas ukuran besar yang berbentuk ruangan.

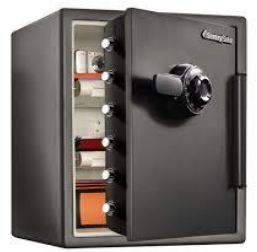

Gambar 1 Brankas

\subsection{Sensor SidikJari/Fingerprint}

Sensor Sidik Jari/Fingerprint merupakan sebuah alat elektronik yang berfungsi untuk membaca sidik jari pengguna dengan cara menerapkan sensor scanning guna keperluan verifikasi identitas. Sensor Fingerprint biasanya digunakan pada beberapa peralatan elektronik seperti smartphone, pintu masuk rumah/kamar, alat absensi karyawan dan berbagai macam peralatan elektronik yang membutuhkan tingkat keamanan yang tinggi, dan hanya bisa di akses oleh pengguna itu sendiri.

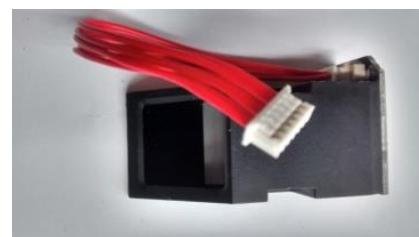

Gambar 2 Sensor SidikJari/Fingerprint

\subsection{Mikrokontroler}

Menurut

Setiaware' Oon

(2011:1)

Mikrokontroler adalah suatu IC dengan kepadatan yang sangat tinggi, dimana semua bagian yang diperlukan untuk suatu kontroler sudah dikemas dalam satu keping, biasanya terdiri dari CPU (Central Processing Unit), RAM (Random Access Memory),
EEPROM/EPROM/PROM/ROM, I/O, Serial \& Parallel, Timer, Interupt Controller.

\subsection{Arduino UNO}

Arduino Uno sebenarnya adalah salah satu mikrokontroler yang berbasis pada ATmega16. Modul ini sudah dilengkapi dengan berbagai hal yang dibutuhkan untuk mendukung mikrokontroler untuk bekerja, tinggal sambungkan ke power suply atau sambungkan melalui kabel USB ke PC Arduino Uno ini sudah siap sedia. Arduino Uno ini memilki 14 pin digital input/output, 6 analog input, sebuah resonator keramik $16 \mathrm{MHz}$, koneksi USB, colokan power input, ICSP header, dan sebuah tombol reset. Arduino Uno R3 adalah seri terakhir dan terbaru dari seri Arduino USB.

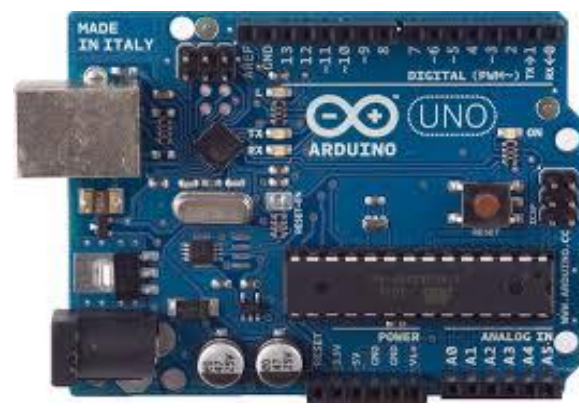

Gambar 3 Arduino Uno

\subsection{Selenoid Door Lock}

Solenoid Door Lock adalah salah satu solenoid yang difungsikan khusus sebagai solenoid untuk pengunci pintu secara elektronik. Solenoid ini mempunyai dua sistem kerja, yaitu Normaly Close (NC)dan Normaly Open (NO).

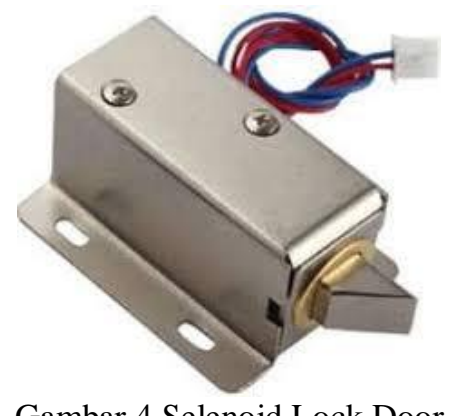

\subsection{Buzzer}

Menurut Indraharja (2012) Buzzer adalah sebuah komponen elektronika yang berfungsi untuk mengubah getaran listrik menjadi getaran suara. Pada dasarnya prinsip kerja buzzer hampir sama dengan loud speaker, jadi buzzer juga terdiri dari kumparan yang terpasang pada diafragma dan kemudian kumparan tersebut dialiri arus sehingga menjadi elektromagnet, kumparan tadi akan tertarik ke dalam atau keluar, tergantung dari arah arus dan polaritas magnetnya, karena kumparan dipasang pada diafragma maka setiap gerakan kumparan akan 
menggerakkan diafragma secara bolak-balik sehingga membuat udara bergetar yang akan menghasilkan suara.

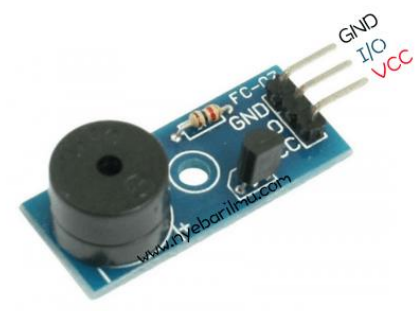

Gambar 5 Buzzer

\subsection{LCD (Liquid Cryistal Display)}

LCD (Liquid Crystal Display) adalah suatu jenis media tampil yang menggunakan kristal cair sebagai penampil utama. LCD sudah digunakan diberbagai bidang misalnya alal-alat elektronik seperti televisi, kalkulator, atau pun layar komputer.Pada postingan aplikasi LCD yang dugunakan ialah LCD dot matrik dengan jumlah karakter 2 x 16. LCD sangat berfungsi sebagai penampil yang nantinya akan digunakan untuk menampilkan status kerja alat.

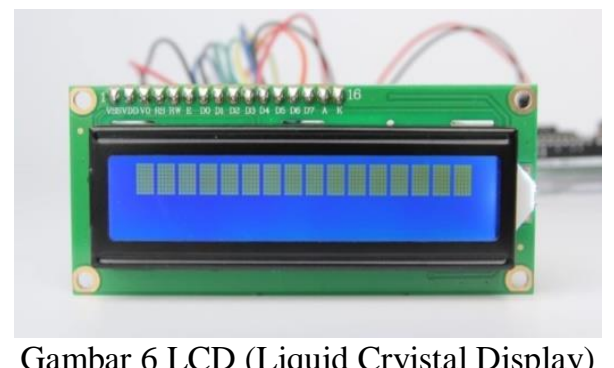

\section{METODE PENELITIAN}

3.1. Langkah-langkah Model Pengembangan R\&D(Research and Development)

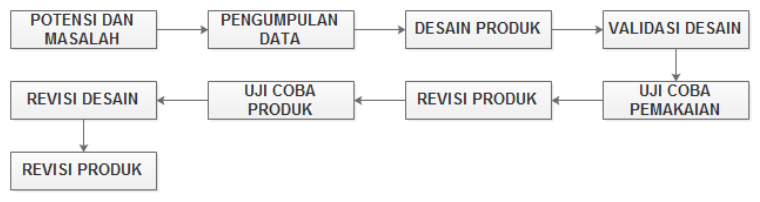

Penjelasan dari gambar tersebut yaitu :

1. Pada tahap ini diawali dengan menganalisis perlunya pengembangan untuk alat pengaman pada pintu brankas serta kelayakan syarat-syarat untuk media yang diperlukan.

2. Setelah itu melakukan tahap desain penetapan dan perencanaan serta perancanganproduk berdasarkan informasi yang didapat dari tahapan sebelumnya.

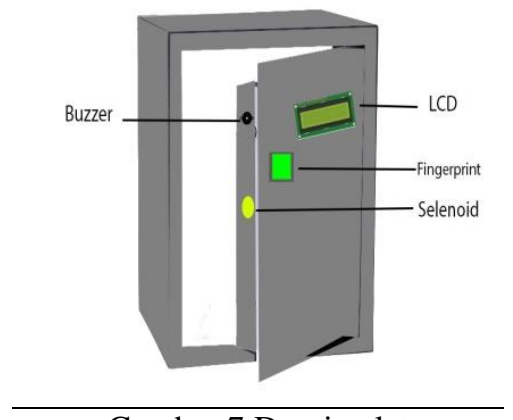

Gambar 7 Desain alat

(a) Mikrokontroler atau Arduino Uno

Pada mikrokontroler ini menggunakan Arduino Uno yang digunakan sebagai pengendali dari seluruh komponen yang terhubung ke Arduino Uno. Pengendalian tersebut bertujuan agar modul-modul yang terhubung keArduino Uno dapat berjalan sesuai program.

(b) Sensor Sidik Jari/Fingerprint

Pada tahap ini sensor Sidik Jari/Fingerprint berfungsi sebagai akses utama dalam membuka pintu brankas

(c) Buzzer

Buzzer digunakan sebagai media output dari sensor Sidik Jari/Fingerprint dan output dari sensor Sidik Jari/Fingerprint berupa suara. Suara akan aktif apabila akses pada sensor Sidik Jari/Fingerprint ditolak atau tidak terdeteksi .

(d) Selenoid door lock

Selenoid Lock Door disini berfungsi sebagai output, alat ini akan berfungsi apabila akses pada sensor Sidik Jari diterima dan sinyal akan dikirimkan ke Selenoid Door Lock lalu pintu otomatis akan terbuka.

(e) LCD (Liquid Cryistal Display)

LCD (Liquid Cryistal Display)berfungsi sebagai output, alat ini fungsinya menampilkan status berhasilnya akses dari sensor Sidik Jari/Fingerprint.

Tujuan dari perancangan hardware (perangkat keras) adalah untuk membuat suatu acuan dasar dalam membuat rangkaian. Desain rancangan dilakukan berdasarkan rancangan diagram blok dan setiap alat mempunyai fungsi tertentu, sementara pemilihan komponen dilakukan setelah rangkaian dibuat.

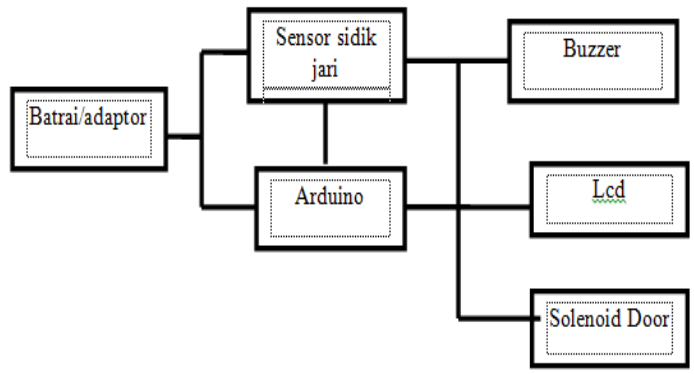

Gambar 8 Diagram blok 
Berdasarkan diagram blok pada Gambar 8 diatas menjelaskan bahwa batrai/adaptor sebagai sumber tegangan memberikan daya kepada Arduino, kemudian sensor Sidik jari/Finger print memberikan inputan data ke Arduino. Selanjutnya Arduino mengoutputkan data ke LCD, Buzzer, dan Selenoid Door locksehingga pintu brankas akan terbuka.

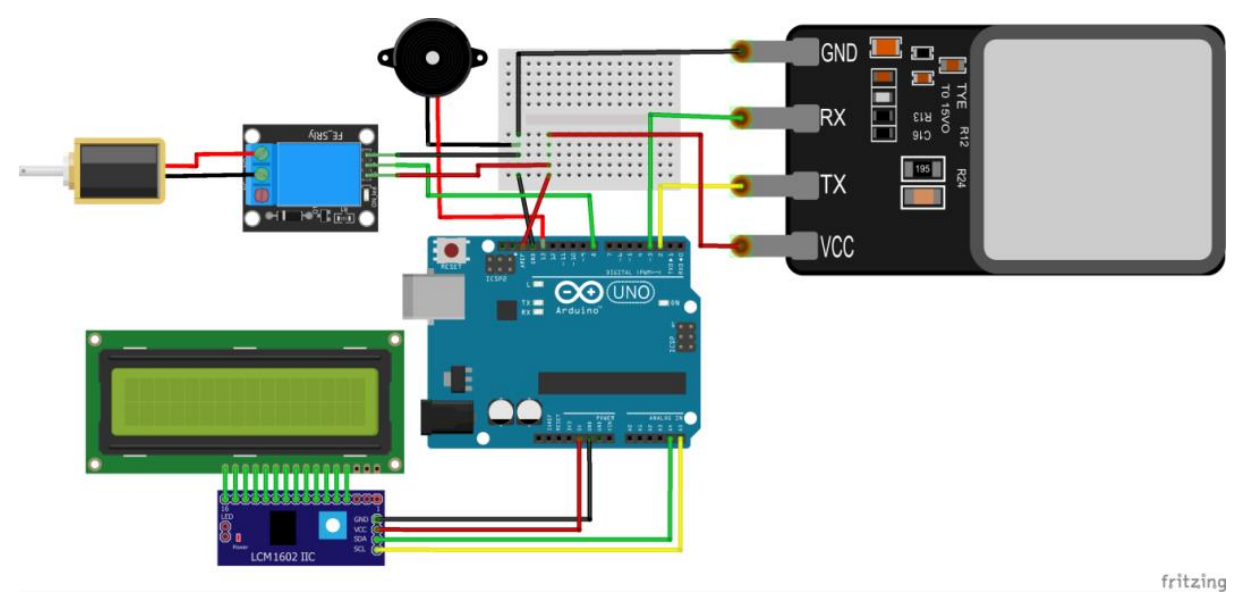

Gambar 9 Rangkaian alat

Tabel 1 Konfigurasi Pin

\begin{tabular}{|c|c|}
\hline Pin & Komponen \\
\hline VCC & VCC pada I2C \\
\hline GND & GND pada I2C \\
\hline A5 & SCL pada I2C \\
\hline A4 & SDA pada I2C \\
\hline Pin 2 & TX \\
\hline Pin 3 & RX \\
\hline GND & GND Buzzer \\
\hline VCC & NO Relay \\
\hline Pin 13 & VCC Buzzer \\
\hline Pin 8 & COM Relay \\
\hline GND & NC Relay \\
\hline
\end{tabular}

Alur Flowchat atau Perangkat Lunak :

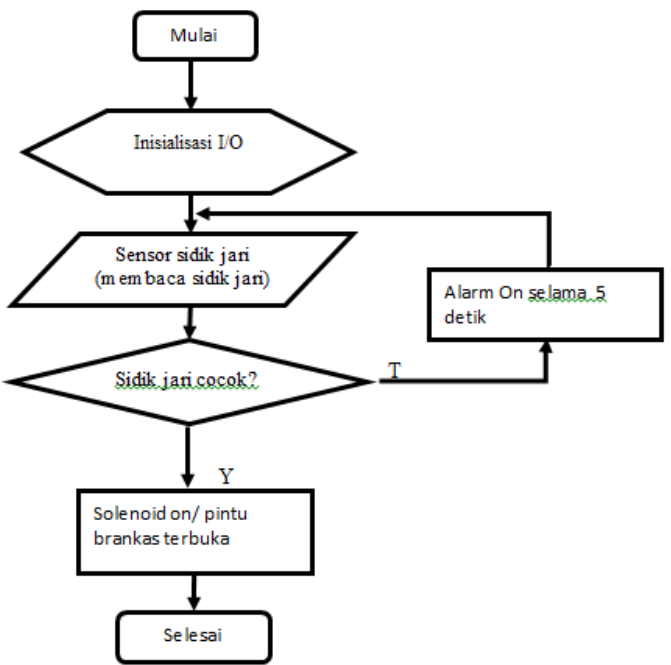

Gambar 10 Flowchart Alat pengaman brankas

Pembahasan dari gambar 7 flowchat sistem alat pengaman brankas:

- Terminator, Mulai merupakan kondisi dimana awal system mulai bekerja

- Preparation Inisialisasi I/O, merupakan proses monitoring semua komponen yang bekerja pada alat yaitu diantaranya sensor sidik jari, keypad, LCD, buzzer, solenoid door lock, apakah komponen keseluruhan sudah siap untuk digunakan atau tidak. Dan juga untuk menentukan komponen-komponen mana saja yang menjadi input dan mana yang menjadi output.

- Input/output data, Memasukan sidik jari pada sensor sidik jari, merupakan proses untuk input maupun output data pada sensor

- Decision, Sidik jari cocok/diterima merupakan proses yang menunjukan hasil baik diterima atau ditolak oleh alat

- On page connector, buzzer merupakan bagian penghubung dengan komponen lainya jika terjadi penolakan pada sensor

- Proses, solenoid on merupakan pengolah data jika semua sensor diterima

- Terminator, selesai merupakan kondisi akhir dari sistem

3. Selanjutnya kita ketahap pengembangan (development) yaitu tahap merealisasikan apa yang telah dibuat dalam tahap desain agar menjadi sebuah produk.

4. Setelah itu tahap selanjutnya yaitu implementasi dengan menerapkan rancangan alat pengaman brankas menggunakan sensor sidik jari berbasis arduino yang telah dibuat dalam wujud yang nyata guna melihat sistem maupun rancangan yang telah siap diuji coba dan ditahapan implementasi ini kita bisa melihat apakah alat sudah berhasil berjalan sesuai dengan program dan proses yang kita jalankan atau belum. 
5. Dan tahapan yang terakhir yaitu tahapan evaluasi , merupakan proses untuk menganalisa program yang sudah dijalankan, bilamana ditahap implementasi masih terdapat kekurangan dan kelemahan. Dan jika pada tahap implementasi tidak terdapat perubahan atau revisi lagi maka rancangan alat pengaman pada brankas menggunakan sensor sidik jari berbasis arduino layak digunakan.

\subsection{Teknik Pengumpulan Data}

(a) Wawancara adalah proses pengumpulan data berupa tanya jawab terhadap narasumber yang dilakukan secara tatap muka dengan menggali informasi sumber data setelah membuat alat.

(b) Observasi merupakan Teknik pengumpulan data dengan proses langsung terjun kelapangan untuk mengamati permasalahan yang terjadi secara langsung dilokasi kejadian,proses ini dlakukan secara sistematik kejadian-kejadian, perilaku, objek-objek yang dilihat dan hal-hal lain yang perlu diperlukan guna mendukung penelitian yang sedang berlangsung.

(c) Studi Literatur metode pengumpulan data dengan cara mengumpulkan literatur, jurnal, paper dan bacaan-bacaan yang ada kaitannya dengan judul penelitian.

\section{HASIL DAN PEMBAHASAN}

\subsection{Hasil Pengujian Alat}

Alat pengaman pada brankas ini dilengkapi dengan Arduino UNO yang berfungsi sebagai pengontrol ke semua sensor dan komponen lainya, sensor Sidik Jari yang berfungsi sebagai sensor untuk akses membuka pintu brankas, LCD (liquid crystal display) sebagai tampilan notifikasi jika akses pada sidik jari diterima atau gagal, selenoid doorlock output pengunci pada pintu brankas, dari hasil pengujian ini dapat digunakan ketika pintu brankas tertutup.

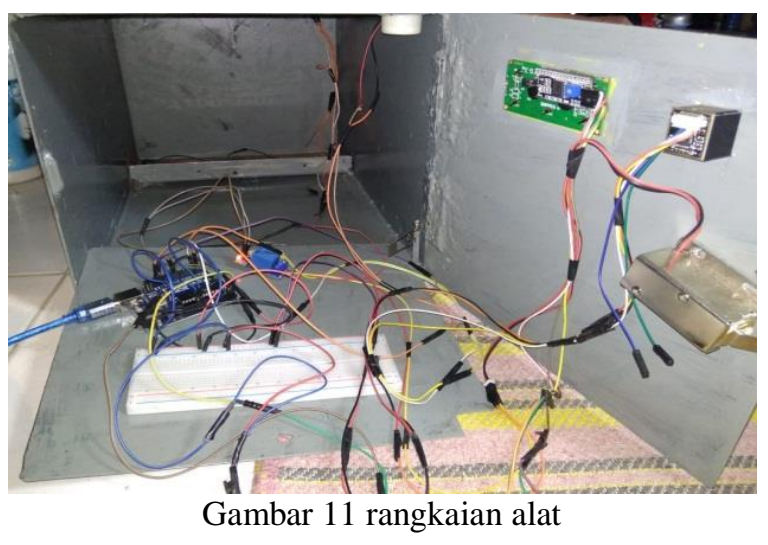

Dimulai dengan mencoba sensor sidik jari dengan menggunakan jari penggguna, sebelum mencoba sistem pengaman pada pintu brankas jari pengguna harus didaftarkan terlebih dahulu dengan cara masuk ke enroll pada program Arduino UNO.

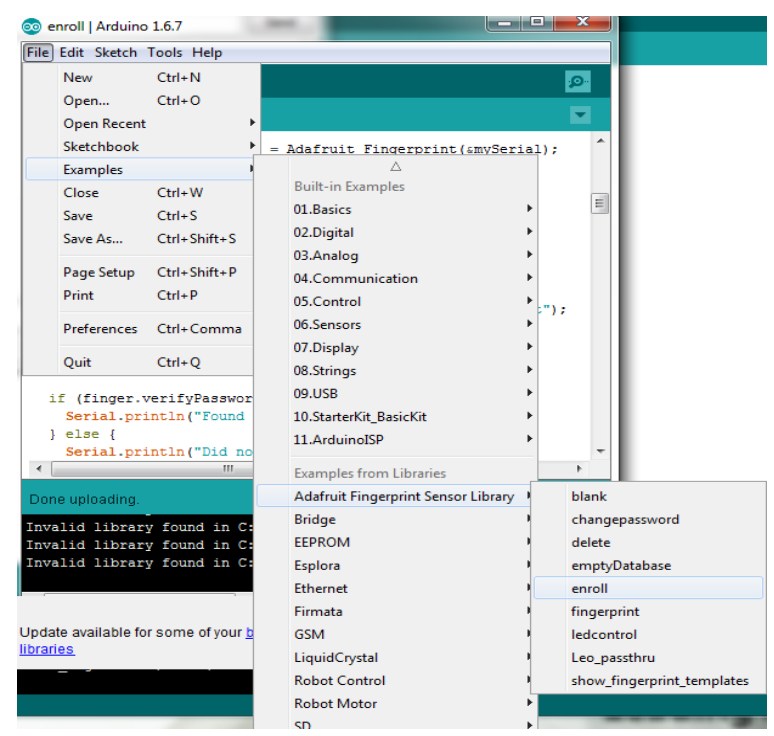

Gambar 12 langkah-langkah pendaftaran sidik jari

Pada gambar 12 diatas menunjukan langkahlangkah pertama saat mendaftarkan sidik jari pengguna dengan menggunakan aplikasi Arduino yang telah terinstal pada $\mathrm{pc} /$ laptop pengguna

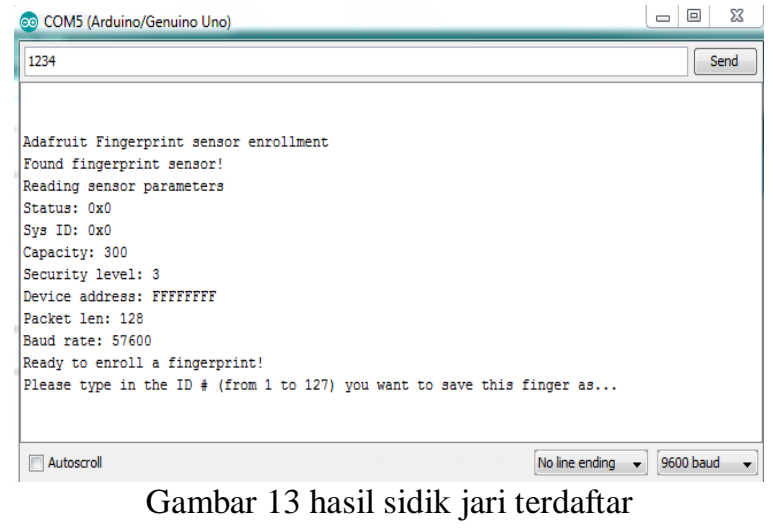

Pada gambar 13 telah terlihat bahwa sidik jari pengguna sudah terdaftarkan dan langkah berikutnya pengguna harus mencoba sidik jari yang sudah terdaftarkan pada gambar yang akan dijelaskan dibawah ini : 


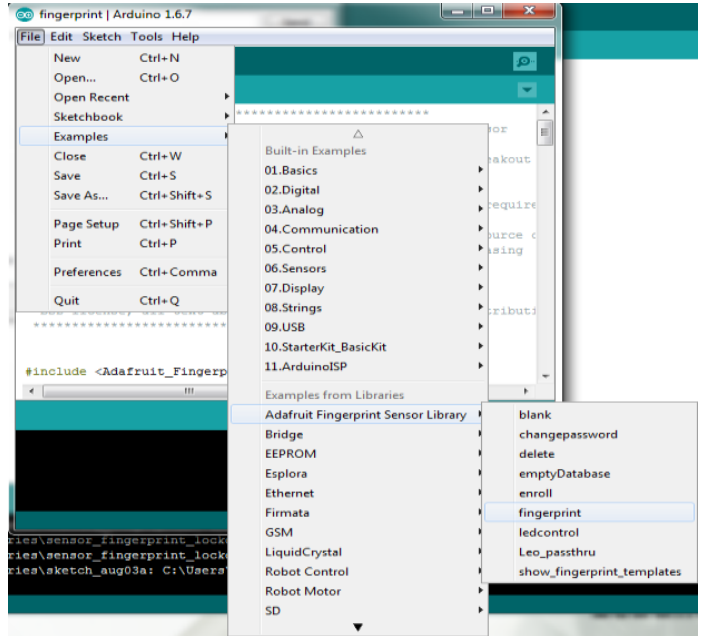

Gambar 14 langkah-langkah percobaan pada sensor sidik jari

Pada gambar 14 diatas terlihat langkah-langkah percobaan untuk sensor sidik jari pengguna yang sudah didaftarkan sebelumnya.

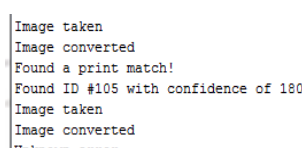

Autosscoll

Gambar 15 hasil dari percobaan sensor sidik jari

Pada gambar 4.11 diatas terlihat bahwa sidik jari dari pengguna sudah terdeteksi dan sudah bisa digunakan pada sistem pengaman yang sudah dibuat. Program dari sistem pengaman yang sudah dibuat bisa dilihat pada halaman lampiran

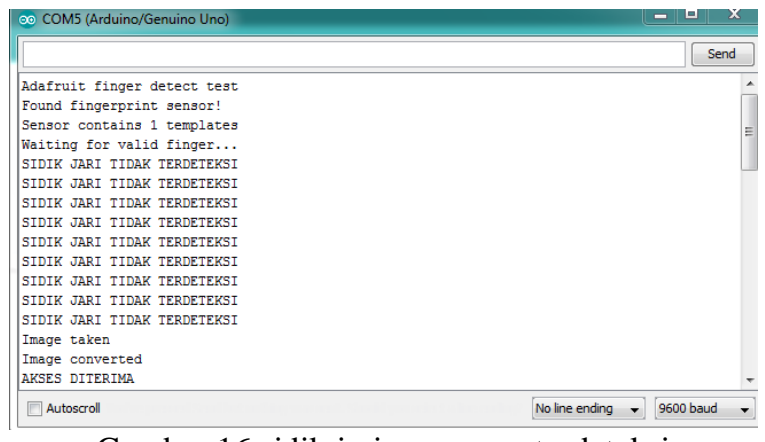

Gambar 16 sidik jari pengguna terdeteksi

Pada gambar 16 diatas terlihat bahwa sidik jari pengguna telah terdeteksi dan akses diterima oleh sistem pengaman.

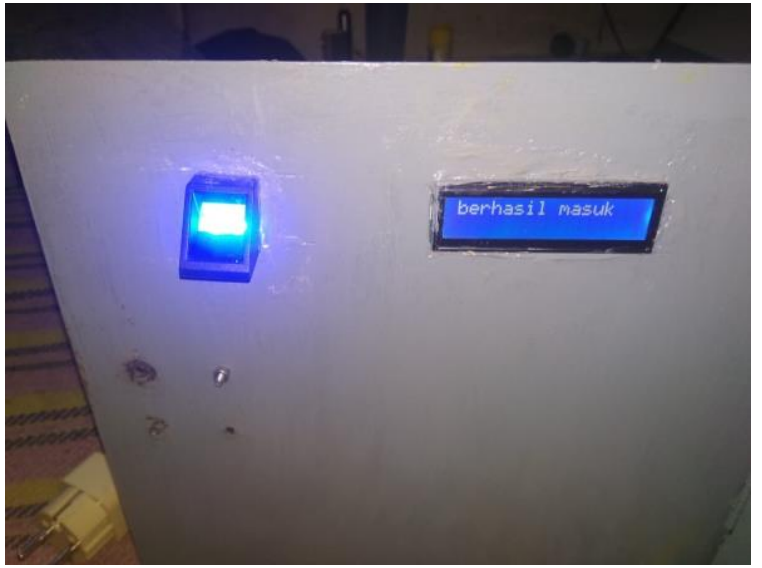

Gambar 17 notifikasi berhasil masuk pada LCD

Pada gambar 17 diatas menunjukan hasil sidik jari dari pengguna yang telah berhasil terdeteksi melalui LCD yang berfungsi sebagai notifikasi.

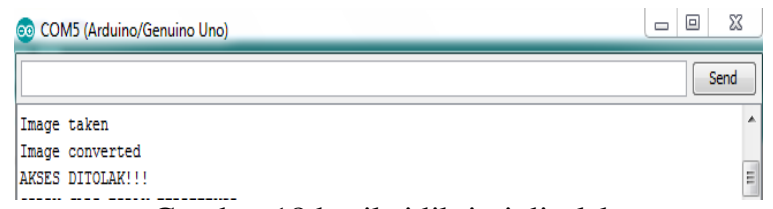

Gambar 18 hasil sidik jari ditolak.

Pada gambar 18 diatas terlihat bahwa sidik jari dari pengguna tidak terdeteksi dan akses pada sistem pengaman ditolak

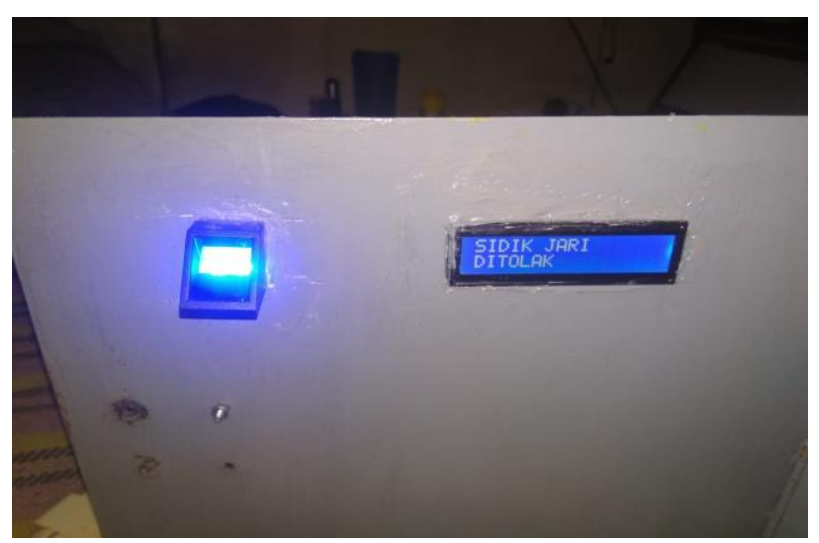

Gambar 19 notifikasi akses ditolak pada LCD

Pada 19 menunjukan bahwa akses pada sidik jari pengguna ditolak dan terdeteksi pada LCD yang berfungsi sebagai notifikasi di sistem pengaman yang digunakan. Jika sidik jari ditolak maka buzzer pada rangkaian akan otomatis menyala. 
Table 2 hasil pengujian pada keseluruhan alat

\begin{tabular}{|c|c|c|c|c|c|c|}
\hline No. & $\begin{array}{c}\text { Uji coba dengan } \\
\text { menggunakan jari } \\
\text { pengguna }\end{array}$ & $\begin{array}{c}\text { Status sensor } \\
\text { sidik jari }\end{array}$ & $\begin{array}{c}\text { Status selenoid } \\
\text { doorlock }\end{array}$ & Status buzzer & $\begin{array}{c}\text { Status } \\
\text { LCD }\end{array}$ & $\begin{array}{c}\text { Status } \\
\text { Akurasi }\end{array}$ \\
\hline 1. & Jari 1 & Terdeteksi & $\begin{array}{c}\text { Berhasil } \\
\text { terbuka }\end{array}$ & Mati & Terkirim & Akurat \\
\hline 2. & Jari 2 & Tidak terdeteksi & Tidak terbuka & Menyala & Terkirim & Akurat \\
\hline 3. & Jari 1 & Tidak terdeteksi & Tidak terbuka & Menyala & Terkirim & Tidak akurat \\
\hline 4. & Jari 1 & Tidak tersedia & Tidak terbuka & Menyala & Terkirim & Tidak akurat \\
\hline 5. & Jari 1 & Terdeteksi & $\begin{array}{c}\text { Berhasil } \\
\text { terbuka }\end{array}$ & Mati & Terkirim & Akurat \\
\hline
\end{tabular}

\section{KESIMPULAN DAN SARAN}

\subsection{Kesimpulan}

Dari pengujian dan pembahasan tentang perancangan alat pengaman brankas menggunakan sensor sidik jari berbasis arduino. Penulis dapat menyimpulkan bahwa :

1. Perancangan alat pengaman brankas menggunakan sensor sidik jari berbasis arduino dapat telah berhasil dirancang dan dibuat dengan menggunakan mikrokontroler arduino UNO dan komponen-komponen yang lain sesuai dengan desain yang telah dibuat.

2. Rancang bangun alat pengaman brankas menggunakan sensor sidik jari berbasis arduino UNO dilakukan dengan menggunakan arduino UNO sebagai pengendali sistem dan komponen, sensor fingerprint berungsi sebagai input data sidik jari pengguna dan terhubung pada relay yang mengontrol buka nya solenoid door, dilengkapi dengan LCD untuk menampilkan lama berhasil atau tidaknya akses yang dilakukan pengguna terhadap sensor fingerprint, dan buzzer sebagai output akan menyala ketika akses ditolak atau tidak berhasil diverifikasi.

3. Pengujian kelayakan dilakukan dengan mengujikan alat yang telah selesai secara langsung kepada user. Dengan kesimpulan yang didapat bahwa alat dapat berfumgsi sebagaimana fungsinya dalam sistem pengamanan pada pintu brankas

\subsection{Saran}

Pembuatan Rancang bangun alat pengaman brankas menggunakan sensor sidik jari berbasis arduino UNO, diharapkan dapat dikembangkan dimasa depan sehingga menjadi lebih mudah,efisien,dan modern untuk penggunanya. Adapun saran yang dapat diberikan penulis adalah :

1. Pengembangan pada penambahan sensor pada pengamanannya dapat lebih memaksimalkan tingkat kemanan pada pintu brankas

2. Pengembangan pada desain alat sehingga dapat lebih sederhana dan menarik bagi user

\section{DAFTAR PUSTAKA}

[1] Eni Yuliza, Toibah Umi Kalsum.2015. "ALAT KEAMANAN PINTU BRANKAS BERBASIS SENSOR SIDIK JARI DAN PASSOWORD DIGITAL DENGAN MENGGUNAKAN MIKROKONTROLER ATMEGA 16" dalam Jurnal Media Infotama Vol. 11 No. 1, Februari 2015

[2] Anton Yudhana, Sunardi, Priyatno.2018. "PERANCANGAN PENGAMAN PINTU RUMAH BERBASIS SIDIK JARI MENGGUNAKAN METODE UML"dalam jurnal teknologi Universitas Muhammadiyah Jakarta Volume 10 No.2 Juli 2018

[3] Annisya, LinggaHermanto, Robby Candra.2017. "SISTEM KEAMANAN BUKA TUTUP KUNCI BRANKAS MENGGUNAKAN SIDIK JARI BERBASIS ARDUINO MEGA"dalam Jurnal Informatika dan Komputer Volume 22 No. 1, April 2017

[4] Geo Fillial, AgivWinagi, Triul iNovianti.2019. "Rancang Bangun Pintu Otomati sdengan Menggunakan RFID"dalam Jurnal Teknik Elektro Dan Komputer Triac Vol. 6 No. 12019

[5] Ade Mubarok, Ivan Sofyan, Ali Akbar Rismayadi, Ina Najiyah.2018. "Sistem Keamanan Rumah Menggunakan RFID, Sensor PIR dan Modul GSM Berbasis Mikrokontroler"dalam JURNAL INFORMATIKA, Vol.5 No.1 April 2018

[6] Hendra Saputra, MaryoArrachman, Rizky Haryansyah.2014.” Sistem Keamanan Brankas Menggunakan Sensor Magnet dalam Skripsi Sekolah Tinggi Manajemen Informatika Dan Komputer Palcomtech Palembang, 24 Februari 2014

[7] Muhammad Chamdun1, Adian Fatchur Rochim2, Eko Didik Widianto.2014."'SISTEM KEAMANAN BERLAPIS PADA RUANGAN MENGGUNAKAN RFID (RADIO FREQUENCY IDENTIFICATION) DAN KEYPAD UNTUK MEMBUKA PINTU SECARA OTOMATIS"dalam Jurnal Teknologi dan Sistem Komputer, Vol 2, No.3 Tahun 2014 